\title{
BIOLOGICAL INFLUENCE OF SOME MICROORGANISMS ON OLIVE MILL WASTEWATER
}

\author{
ISMAIL , H. ${ }^{1}$, AZZA A. M. ABD EL-ALL ${ }^{1}$ and HANAN A. M. HASSANEIN ${ }^{2}$ \\ 1. Soils, Water and Environment Research Institute, ARC, Giza, Egypt \\ 2. Animal Production Research Institute, ARC, Giza, Egypt
}

(Manuscript received 12 July 2012)

\begin{abstract}
A cyanobacterial strain, Spirulina platensis besides two strains of green algae, Dunaliella saline and Chlorella vulgaris and the fungus Pleurotus columbinus were propagated on $10 \%$ concentration of olive mill wastewater at a steady state. For Pleurotus columbinus, it was also propagated on the previous concentration at an agitated state. The most efficient strain for decreasing chemical oxygen demand and phenolic compounds was Pleurotus columbinus propagated at $150 \mathrm{rpm}$ in shaker which diminishes them by laccase enzyme. The second efficient strain in decreasing, chemical oxygen demand and phenolic compounds was Chlorella vulgaris followed by Spirulina platensis while Dunaliella saline which was the least efficient one. Pleurotus columbinus was propagated either in a steady state or an agitated at $150 \mathrm{rpm}$ in shaker donate high amount release of total carbohydrates. The main observation is the small value of growth which may be due to absence of nutrients in the medium. The use of such effective strains will help in minimizing the hazard impact of olive mill wastewater. Accordingly, the waste water produced should be primary treated before being dumped in water bodies.
\end{abstract}

\section{INTRODUCTION}

Olive oil industry is one of the most important industries in the world especially in the Mediterranean countries. Many environmental problems take place from that industry due to the production of huge amounts of wastewater which contain heavy burden of organic matter and poly phenolic compounds. Olive mill wastewater (OMWW) when discharged into surface water which used for irrigating soils affects physical and chemical properties of soils such as porosity and pH. In addition, the high concentration of reducing sugars stimulate microbial respiration and lower dissolving oxygen concentrations (Niaounakis and Halvadakis, 2006). In olive mill wastewater, chemical oxygen demand (COD) could reach up to $220 \mathrm{~g} / \mathrm{l}$ as was mentioned by Papanikolaou et al. 2008. Several studies were carried out to reduce the phenolic compounds and COD content of this wastewater by using different treatment methods. Green algae and cyanobacteria play an important role in bioremediation of polluted wastewater with heavy metals and organic polycyclic hydrocarbons pollutants. (Torres et al., 2008). Semple et al. (1999) showed that 
eukaryotic algae like Chlamydomonas, Chlorella, Dunaliella and Scenedesmus are capable of biotransforming and biodegrading aromatic pollutants commonly in nature and wastewater, enhancing the degradation potential of the micro-biota and eliminating pollutants from the respective ecosystem. The most promising microorganisms of white rot fungi such as Coriolus, Phanerochaete, Lentinula, Ganoderma and Pleurotus have the ability to degrade poly phenolic compounds, lignin, removal of COD and decolonization ( Anastasiou et al., 2011).

This work aims at reducing the phenolic compounds and COD from OMWW using different algal strains propagated in a steady state for 30 days compared to Pleurotus colombinus propagated in both a steady state and an agitated state at the same period.

\section{MATERIALS AND METHODS}

\section{Materials}

\section{Microorganisms used}

One strain of cyanobacteria ( Spirulina platensis ) and two strains of green algae (Dunaliella saline and Chlorella vulgaris) were obtained from Agricultural Microbiology Research Department, Soils, Water and Environment Res. Inst. (SWERI), Agric. Res., Center (ARC) . One strain of white rot fungi ( Pleurotus columbinus ) was obtained from Unit of Mushroom Production, Faculty of Agriculture, Ain Shams University .

Spirulina platensis was grown on Zarrouk medium (Zarrouk, 1966). Dunaliella saline was grown on Johnsons medium (Johnson et al., 1968). Bold medium (Nichols and Bold, 1965) was used for the green alga Chlorella vulgaris. Pleurotus columbinus was grown on Potato Dextrose Agar medium, PDA (Martin, 1950).

\section{Biological Treatments}

All microbial strains were cultured on $10 \%$ concentration of olive. Mill wastewater (OMWW) at steady state and at ambient temperature. Pleurotus columbinus was also grown in shaker at $150 \mathrm{rpm}$ and at ambient temperature. Pleurotus columbinus which was grown in shaker has a symbol * (Pleurotus columbinus*)

\section{Methods}

\section{Determination of chemical constituents of OMWW}

Chemical oxygen demand (COD) was determined according to the method described by APHA et al. (1992). Total phenols were determined spectrophotometrically as described by Swain and Hillis (1959). Total sugars were determined by the method of Dubois et al. (1956). Dry weight was determined by drying the biomass in the oven at $70^{\circ} \mathrm{C}$. 


\section{RESULTS AND DISCUSSION}

The microorganisms used varied in their effects on $\mathrm{pH}$ changes (Table 1). It is clearly noticed that cultivation of cyanobacteria represented by Spirulina platensis elevated $\mathrm{pH}$ of the medium than the other microorganisms during propagation periods. This might be due to the formation of $\mathrm{CO}_{2} / \mathrm{H}_{2} \mathrm{CO}_{3} / \mathrm{HCO}_{3}{ }^{-1} / \mathrm{CO}_{3}^{-2}$ system which is a very useful buffer system for maintaining the alkaline $\mathrm{pH}$ which helps to prevent carbon depletion (Keskinkan et al., 2012).

Table 1. Periodical fluctuations in medium $\mathrm{pH}$ values due to growth of the various microorganisms. *

\begin{tabular}{|c|c|c|c|c|}
\hline $\begin{array}{c}\text { Reriod per day } \\
\text { Microbe strain }\end{array}$ & Zero time & 10 days & 20 days & 30 days \\
\hline Spirulina platensis & 4.6 & 8.4 & 8.3 & 8.2 \\
\hline Dunaliella saline & 4.6 & 4.7 & 4.6 & 4.8 \\
\hline Chlorella vulgaris & 4.6 & 5.5 & 5.5 & 6.2 \\
\hline Pleurotus columbinus & 4.6 & 5.4 & 5.2 & 5.0 \\
\hline Pleurotus columbinus* & 4.6 & 5.5 & 5.6 & 5.7 \\
\hline
\end{tabular}

*Propagation of Pleurotus columbinus on $10 \%$ concentration of olive mill wastewater in an agitated state at $150 \mathrm{rpm}$ for 30 days.

Table (2) shows that Dunaliella saline exhibited the least effect on COD in diluted OMWW during treatment periods ( $40.5 \%$ removal after 30 days of propagation), while Pleurotus columbinus* was the highest $(81.0 \%$ removal after the same elaborated period). Chlorella vulgaris and Pleurotus columbinus propagated in steady state were mostly in the same effect throughout treatment periods. For algal strains, Chlorella vulgaris was the most affecting COD followed by Spirulina platensis then Dunaliella saline. These results agree with Markoua et al. (2012) who stated that Spirulina platensis can remove 73.18 of COD presented in OMWW. Morever, Valderrama et al. (2002) reported that Chlorella vulgaris propagated on $10 \%$ concentration of OMWW can diminish COD to $61 \%$. OMWW inoculated by Pleurotus columbinus at steady state and agitated at $150 \mathrm{rpm}$ removed 66.7 and $81.0 \%$ of COD after 30 days of propagation, respectively. 
Table 2. COD values of microbial strains propagated on $10 \%$ concentration of OMWW through 30 days. *

\begin{tabular}{|c|c|c|c|c|}
\hline \multirow{2}{*}{$\begin{array}{l}\text { Microbial } \\
\text { Strains }\end{array}$} & $\begin{array}{c}\text { Content } \\
\mathrm{g} / \mathrm{l}\end{array}$ & $\begin{array}{c}\text { Content } \\
\mathrm{g} / \mathrm{l}\end{array}$ & $\begin{array}{c}\text { Content } \\
\mathrm{g} / \mathrm{l}\end{array}$ & $\begin{array}{c}\text { Content } \\
\mathrm{g} / \mathrm{l}\end{array}$ \\
\hline $\begin{array}{c}\text { Spirulina platensis } \\
\text { Dunaliella saline }\end{array}$ & 4.2 & 3.3 & 2.2 & 1.7 \\
\hline Chlorella vulgaris & 4.2 & 3.3 & 3.0 & 2.5 \\
\hline Pleurotus columbinus & 4.2 & 2.7 & 2.0 & 1.6 \\
\hline Pleurotus columbinus* & 4.2 & 1.8 & 2.0 & 1.4 \\
\hline LSD 0.05 & 0 & 0.92 & 1.03 & 0.3 \\
\hline
\end{tabular}

*Propagation of Pleurotus columbinus on $10 \%$ concentration of olive mill wastewater in an agitated state at $150 \mathrm{rpm}$ for 30 days.

The results in Table (3), reveal obvious phenol removal by Pleurotus columbinus either in steady state or agitation than any algal strain used. On the other side, Spirulina platensis shows high efficiency in phenol removal followed by Chlorella vulgaris then Dunaliella saline. Elimination or decreasing phenolic compounds is related to phenol oxidase enzyme presented in some genera of algae such as Spirulina and Chlorella, or laccase enzyme which is considered one of the family of phenol oxidase enzymes presented in some genera of white rot fungi like Pleurotus. Sherman et al. (1991) stated that a lot of green algae like Chlorella, Stigeoclonium, Microspora, Ulva and Spirogyra have polyphenol oxidase enzyme. Kirkwood et al. (2003) ascribed the capability of Spirulina to deal with pollutants and degrade the phenolic compounds to photosynthesis phenomena which make cyanobacteria do not need any external carbon source because of $\mathrm{CO}_{2}$ fixation. Kunamneni et al. (2007) mentioned that Pleurotus produces a group of enzymes such as laccase, manganese peroxidase and veratryl alcohol oxidase that have the ability to degrade poly phenolic compounds. 
Table 3. Effect of microbial strains on decreasing of phenolic compounds during 30 days on $10 \%$ concentration of OMWW*

\begin{tabular}{|c|c|c|c|c|}
\hline \multirow{2}{*}{ Period per day } & Zero time & 10 days & 20 days & 30 days \\
\cline { 2 - 5 } strains & $\begin{array}{c}\text { Content } \\
\mathrm{g} / \mathrm{l}\end{array}$ & $\begin{array}{c}\text { Content } \\
\mathrm{g} / \mathrm{l}\end{array}$ & $\begin{array}{c}\text { Content } \\
\mathrm{g} / \mathrm{l}\end{array}$ & $\begin{array}{c}\text { Content } \\
\mathrm{g} / \mathrm{l}\end{array}$ \\
\hline Spirulina platensis & 0.215 & 0.082 & 0.078 & 0.046 \\
\hline Dunaliella saline & 0.215 & 0.158 & 0.133 & 0.114 \\
\hline Chlorella vulgaris & 0.215 & 0.115 & 0.103 & 0.063 \\
\hline Pleurotus columbinus & 0.215 & 0.058 & 0.037 & 0.021 \\
\hline $\begin{array}{c}\text { Pleurotus } \\
\text { columbinus* }\end{array}$ & 0.215 & 0.021 & 0.014 & 0.012 \\
\hline LSD 0.05 & 0 & 0.02 & 0.01 & 0.02 \\
\hline
\end{tabular}

*Propagation of Pleurotus columbinus on $10 \%$ concentration of olive mill wastewater in an agitated state at $150 \mathrm{rpm}$ for 30 days.

Distinct differences in carbohydrate behavior between Spirulina platensis and Dunaliella saline., Chlorella vulgaris that propagation in steady state and Pleurotus columbinus which was propagated in both steady and agitated state towards carbohydrate behavior through propagation on diluted OMWW are observed. Table (4) reveals that algal strains are consumer to carbohydrate, while fungal strain is producer. Chlorella vulgaris is the highest consumers of carbohydrate at 30 days of propagation on $10 \%$ concentration of OMWW, followed by Spirulina platensis then Dunaliella saline at the same condition, while Pleurotus columbinus in steady state is the highest producer than in agitated state. Hodaifa et al. (2009) reported that microalgae consumed total carbohydrate by $65 \%$ and assimilated it to form biomass. The percentage of confirmed carbohydrate is determined by nearly $65 \%$. On the other hand, mushroom production is manipulated to produce exo--polysaccharides used in some potential pharmaceutical application such as lintanine, schyzophyline and grifron D from Lentinula, Schizophyllum and Grifola, respectively. Food manufactures have directly employed exo-polysaccharides of mushrooms by fermentation to prepare drinks or capsules for sales (Wu et al. , 2008). 
Table 4. Total carbohydrate consumed or released during propagation of microbial strains on diluted OMWW through 30 days. *

\begin{tabular}{|c|c|c|c|c|}
\hline \multirow{2}{*}{$\begin{array}{l}\text { Microbial } \\
\text { strains }\end{array}$} & $\begin{array}{c}\text { Ceriod per day } \\
\mathrm{g} / \mathrm{l}\end{array}$ & $\begin{array}{c}\text { Content } \\
\mathrm{g} / \mathrm{l}\end{array}$ & $\begin{array}{c}\text { Content } \\
\mathrm{g} / \mathrm{l}\end{array}$ & $\begin{array}{c}\text { Content } \\
\mathrm{g} / \mathrm{l}\end{array}$ \\
\cline { 2 - 5 } Spirulina platensis & 0.571 & 0.338 & 0.345 & 0.171 \\
\hline Dunaliella saline & 0.571 & 0.463 & 0.505 & 0.395 \\
\hline Chlorella vulgaris & 0.571 & 0.377 & 0.341 & 0.126 \\
\hline Pleurotus columbinus & 0.571 & 1.096 & 2.027 & 2.067 \\
\hline $\begin{array}{c}\text { Pleurotus } \\
\text { columbinus* }\end{array}$ & 0.571 & 1.016 & 1.081 & 1.542 \\
\hline LSD 0.05 & 0 & 0.16 & 0.16 & 0.47 \\
\hline
\end{tabular}

*Propagation of Pleurotus columbinus on $10 \%$ concentration of olive mill wastewater in an agitated state at $150 \mathrm{rpm}$ for 30 days.

Table (5) shows small values of growth throughout all propagation periods. This might be due to absence of nutrients during propagation periods. The high values of growth exist at 20 days of propagation for both Spirulina and Dunaliella while high values of growth are at 10 days propagation for Chlorella vulgaris and Pleurotus which propagated at either steady or agitated state. Obvious decreases in growth were observed for the three strains of algae. These may be due to depletion of nitrogen presented in the medium.

Table 5. Dry weight of Spirulina, Dunaliella, Chlorella and Pleurotus propagated on $10 \%$ of OMWW through 30 days. *

\begin{tabular}{|c|c|c|c|}
\hline \multirow{2}{*}{$\begin{array}{l}\text { Microbial } \\
\text { strains }\end{array}$} & 10 days & 20 days & 30 days \\
\hline Spirulina platensis & $\begin{array}{c}\text { growth } \\
\mathrm{mg} / \mathrm{l}\end{array}$ & $\begin{array}{c}\text { growth } \\
\mathrm{mg} / \mathrm{l}\end{array}$ & $\begin{array}{c}\text { growth } \\
\mathrm{mg} / \mathrm{l}\end{array}$ \\
\hline Dunaliella saline & 860 & 1080 & 50 \\
\hline Chlorella vulgaris & 500 & 1080 & 30 \\
\hline Pleurotus columbinus & 1200 & 1080 & 50 \\
\hline Pleurotus columbinus* & 1200 & 1020 & 1000 \\
\hline LSD 0.05 & 1660 & 1200 & 1100 \\
\hline
\end{tabular}

*Propagation of Pleurotus columbinus on $10 \%$ concentration of olive mill wastewater in an agitated state at $150 \mathrm{rpm}$ for 30 days. 


\section{CONCLUSION}

The results of this study show clearly that either Spirulina platensis, Dunaliella saline or Chlorella vulgaris has the capability to reduce both COD and phenolic compounds as they have phenol oxidase, Pleurotus columbinus is the most efficient microbe to deal with poly phenolic compounds. Pleurotus columbinus also secrets exo-polysaccharides which have many beneficial applications in nutritional and pharmaceutical purposes. Further studies will investigate the role of OMWW treated with Pleurotus columbinus on the aggregation and amendment of soil properties and enhancement of plant growth. From these results, it is recommended to establish a treatment unit for bioremediation of the olive mill wastewater pollutant before being drained in water bodies.

\section{REFERENCES}

1. Anastasiou, C. C., P. Christou, A. Michael, D. Nicolaides and T. P. Lambrou. 2011. Approaches to olive mill wastewater treatment and disposal in cyprus. Environmental Research Journal 5: 49-58.

2. APHA 1992. Standard methods for the examination of water and waste water, $18^{\text {th }}$ ed. Academic Public Health Association, Washington,DC.

3. Dubois, M., K. A. Gilles, J. K. Hamilton, P. A. Repers and F. Smith. 1956. Colorimetric method for determination of sugars and related substances .Analytical chemistry18: 350-356.

4. Hodaifa, H., M. E. Martínez and S. Sánchez. 2009. Daily doses of light in relation to the growth of Scenedesmus obliquus in diluted three-phase olive mill wastewater. Journal of Chemical Technology and Biotechnology. 84: 1550-1558.

5. Johnson, M. K., J. Johnson, D. Maceloroyr, L. Speerh and S. Bruffb. 1968. Effects of salts on the halophilic alga Dunaliella viridis. Journal of Bacteriology 95: 146 11468.

6. Keskinkan, O, O. Lisic, T. Yılmaz, B. Balcl, L. H. Uslu and C. B. Ersu. 2012. Simultaneous Growth of Spirulina platensis and Removal of Hardness in Van Lake Water: Research Article. Clean - Soil, Air, Water, 40 (1): 34-38.

7. Kirkwood, A. E. , C. Nalewajko and R. R. Fulthorpe. 2003. Physiological characteristics of cyanobacteria in pulp and paper waste-treatment sytems.. Journal of Applied Phycology, 15 (4): 325-335.

8. Kunamneni A., A. Ballesteros, F. J. Plou and M. Alcalde. 2007. Fungal laccase - a versatile enzyme for biotechnological applications. Communicating Current 
Research and Educational Topics and Trends in Applied Microbiology FORMATEX ,233-245. A. Méndez-Vilas (Ed.).

9. Markoua, G., I. Chatzipavlidisb and D. Georgakakis. 2012. Cultivation of Arthrospira (Spirulina) platensis in olive-oil mill wastewater treated with sodium hypochlorite . Bioresource Technology, 112: 234-241.

10. Martin, J.D. 1950. Use of acid rose Bengal and Streptomycien in the plate method for estimating soil fungi .Soil Sci., 69: 215.

11. Niaounakis, M. and C. P. Halvadakis. 2006. Olive Processing Waste Management, Volume 5, Second edition : Literature Review and Patent Survey 2nd Edition, Elsevier Ltd, UK.

12. Nichols, H. W. and H. C. Bold. 1965. Trichosarcina polymorpha gen. et sp. nov. J. Phycol. 1: 34-38.

13. Papanikolaou, S., M. Galiotou-Panayotou, S. Fakas, M. Komaitis and G. Aggelis. 2008. Citric acid production by Yarrowia lipolytica cultivated on olive-mill wastewater-based media. Bioresour. Technol. 99 (7): 2419-2428.

14. Semple, K.T., R. B. Cain and S. Schmidt. 1999. Biodegradation of aromatic compounds by microalgae. FEMS Microbiol. Lett. 170: 291-300.

15. Sherman, T. D. , K. C. Vaughn and S. O. Duke. 1991. A limited survey of the phylogenetic distribution of polyphenol oxidase. Phytochemistry , 30 (8 ): 24992506.

16. Swain, T. and W. E. Hillis. 1959. The quantitative analysis of constituent's phenolic. J.Sci. Food Agric.,10: 63-68.

17. Torres, M. A., M. P. Barros, S. C. G. Campos, E. Pinto, S. Rajamani, R. T.Sayre and P. Colepicolo. 2008. Biochemical biomarkers in algae and marine pollution: A review. Ecotoxicology and Environmental Safety 71: 1- 15.

18. Valderrama, L. T., C. M. Del Campo, C. M. Rodriguez, L. E. De Bashan and Y. Bashan. 2002. Treatment of recalcitrant wastewater from ethanol and citric acid production using the microalga Chlorella vulgaris and the macrophyte Lemna minuscula. Water Research, 36 (17): 4185-4192.

19. Wu, C. Y., Z. C. Liang , C. P. Lu and S. H. Wu. 2008. Effect of Carbon and Nitrogen Sources on the Production and Carbohydrate Composition of Exopolysaccharide by Submerged Culture of Pleurotus citrinopileatus. Journal of Food and Drug Analysis, 16 ( 2): 61-67.

20. Zarrouk C. 1966. Contribution á l'étude d'une cyanophycée. Influence de divers facteurs physiques et chimiques sur la croissance et la photosynthése de Spirulina maxima (Setch. Et Gardner) Geitler. Ph. D. Thesis, University of Paris, France. 
التأثير الحيوى لبعض الكائنات الحيه الاقيقه على الماء الناتج من صناعة زيت الزيتون

حسن اسماعيل1 ، عزه احمد محمد عبد العال1 ، حنان احمد محمود حسنين2

$$
\text { 2. 1. معهُ بحوث الاراضسى و المياه و البيئه - مركز البحوث الزراعيه - جيزه - مصر الانتاج الحبوانى - مركز البحوث الزراعيه - جبزه - مصر }
$$

تم استخدام احدى سلالات السيانوبكتريا و هى سبيرولينا بلاتينسيس ، و سلالتين من الطحالب

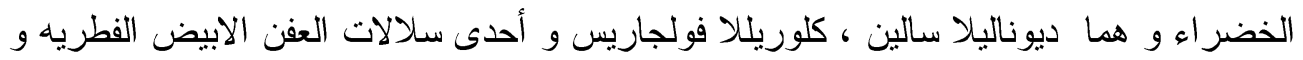
هى بليوروتاس كولومبينوس حيث تمت التتميه عند تركيز 10 \% من الماء الناتج من صناعة زيل زيت

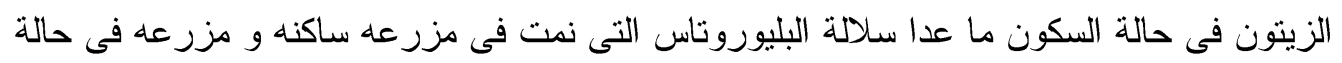

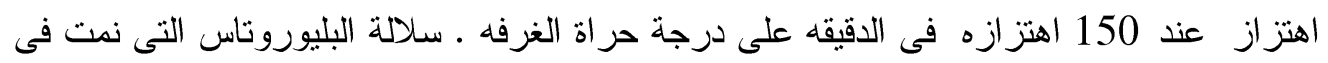

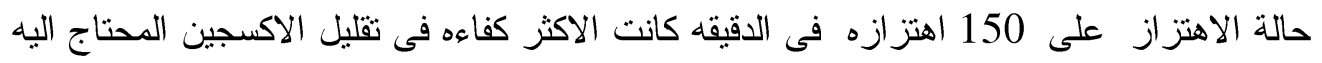

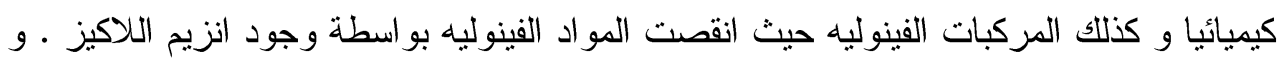

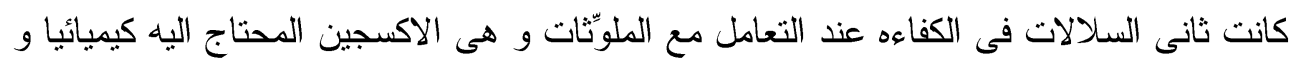

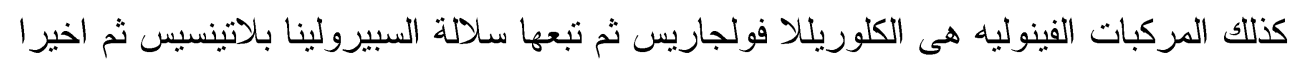
سلالة الديوناليبلا سالين .السلاله الفطريه بليوروتاس كولومبينوس التى نمت سواء فئ في حالة السكون

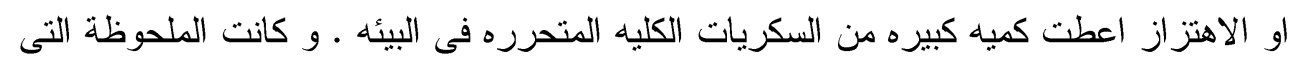
اثارت الانتباه هى ضعف النمو و الذى قد يرجع الى عدم اضافة الى عناصر غذائيه الى بيئة النمو .

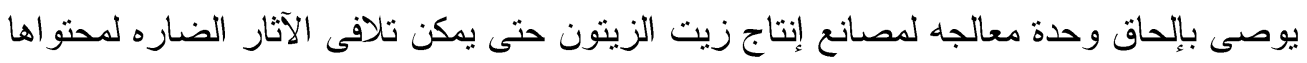

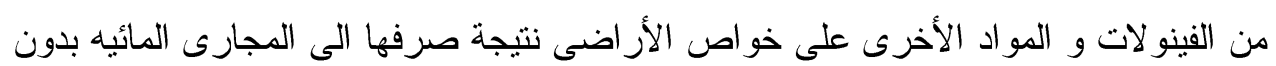
معالجه. 